\title{
Américo Castro's Conversos and the Question of Subjectivity
}

\author{
Miriam Bodian \\ Department of History. University of Texas at Austin-Austin, TX 78712 \\ e-mail: bodian@austin.utexas.edu \\ ORCID iD: http://orcid.org/0000-0002-2230-5281
}

Submitted: 15 March 2017. Accepted: 28 August 2017

\begin{abstract}
Scholars have long puzzled over the disproportionate role played by Judeo-conversos in the innovative cultural currents of sixteenth- and seventeenth-century Spain. Recently, a number of scholars have developed the idea that outstanding converso thinkers and authors shared a sensibility that anticipated modernity (particularly Jewish modernity). One of the key features of this sensibility was subjective consciousness. This article explores the foundational work of Américo Castro on this subject. Drawing from nineteenth-century orientalist discourse, Castro understood the subjective awareness of conversos to be a renewed expression of ancient "semitic" characteristics discernable in medieval Jewish (and Islamic) writing, as well as in the Hebrew Bible. In Castro's view, the conversos' inherent access to their inner life, stimulated by their experience of repression, allowed them to create a literature that became synonymous with Hispanicity. Castro's conversos, in whom the strongly negative characteristics of his Jews have "disappeared," are thus harbingers not of modernity, but of a coalescing Spanish national identity. Yet his essentialized view of converso subjectivity has offered support to recent scholarship on "Marranism" and modernity, which follows Castro in its converso-centric apprehension of subjectivity in early modern Europe.
\end{abstract}

KEYWORDS: Conversos; Marranism; Subjectivity; Early Modern Spain; Orientalism; Antisemitism; Purity of Blood

Citation / Cómo citar este artículo: Bodian, Miriam (2017) “Américo Castro's Conversos and the Question of Subjectivity”. Culture \& History Digital Journal, 6 (2): e018. doi: http://dx.doi.org/10.3989/chdj.2017.018.

RESUMEN: Los Conversos de Américo Castro y la Cuestión de Subjetividad.-Desde hace bastante tiempo, los investigadores se encuentran desconcertados ante el desproporcionado papel de los judeo-conversos dentro de las corrientes renovadoras de la España de los siglos dieciséis y diecisiete. Recientemente, una serie de investigadores ha planteado la idea de que destacados pensadores y autores conversos compartieron un tipo de sensibilidad que anticiparía la modernidad (particularmente, la modernidad judía). Una de las principales características de dicha sensibilidad seria la conciencia subjetiva. Este artículo explora el trabajo fundacional de Américo Castro en este materia. Partiendo de los discursos orientalistas del siglo XIX, Castro interpretó la conciencia subjetiva de los conversos como una expresión renovada de antiguos rasgos "semíticos", discernibles en escritos medievales judíos (e islámicos), así como en la Biblia Hebrea. Desde el punto de vista de Castro, el acceso innato de los conversos a su vida interior, estimulado por su experiencia de la represión, les permitió crear una literatura que se convirtió en sinónimo de españolidad. Los conversos de Castro - para los cuales han desaparecido las características fuertemente negativas de sus judíos - no serían los precursores de la modernidad, sino de una identidad nacional hispana asimiladora. Sin embargo, su visión esencialista de la subjetividad conversa ha servido de base para aportaciones más recientes sobre el "marranismo" y la modernidad, que siguen a Castro en su interpretación converso-centrista de la subjetividad en la temprana modernidad europea.

PALABRAS CLAVE: Conversos; Marranismo; Subjetividad; Siglo de Oro; Orientalismo; Antisemitismo; Limpieza de Sangre

Copyright: (C) 2017 CSIC. This is an open-access article distributed under the terms of the Creative Commons Attribution License (CC BY) Spain 3.0. 
Can we ascertain, using accepted methods of historical inquiry, whether the conversos of early modern Spain had distinctive traits not found (or at least not often found) among "Old Christians" - even generations after the first ancestral conversion? Over many decades, a number of eminent scholars - most, but not all, of them Hispanists - have argued that conversos did exhibit unique traits and for that reason played a distinctive role in Spanish culture (or even in European culture as a whole). This essay seeks to analyze some of the problems inherent in the discussion of converso "exceptionalism" by focusing on one particular claim - namely, that conversos were historically precocious in their tendency to explore inner consciousness - and by examining the argumentation of its earliest proponent, Américo Castro. It is worth exploring the issue of converso "exceptionalism" not only because it remains unresolved, but also because it has been revived in new form in recent decades, enlisting for support the work of Castro and those who followed in his footsteps, while in fact pursuing a quite different course. I'm referring to the discussion of "Marranism" that has flourished in France, Germany, and the United States.

For those not familiar with the literature of "Marranism," let me first summarize its general argument. Scholars involved in this discussion have discerned in the thinking of conversos the seeds of a modern sensibility a way of seeing the world and the self that had few precedents before the sixteenth century. Most of the scholars involved (the most prominent among them is the Israeli scholar Yirmiyahu Yovel) agree on how such a sensibility developed among the Iberian conversos. ${ }^{1}$ The general scheme is as follows. While Iberian society allowed conversos to penetrate its intellectual and religious elites, it denied them a secure, dignified, and stable place - a social and cultural foundation on which to build a stable sense of self. The conversos' sense of insecurity was sustained by stigma and institutionalized discrimination, and by the knowledge that they were particularly vulnerable to inquisitorial prosecution. Under these conditions conversos cultivated a private, often subversive grasp of the world that reflected their social, intellectual and spiritual marginalization and dislocation, thus distinguishing them psychologically and cognitively (in addition to the ancestral distinction) from "Old Christians."

The conversos' situation produced tensions that eventually found relief, according to this general model, in an inner liberation from conventional ways of thinking - that is, from a set of ideas imposed by traditional authority and social conditioning. Put more affirmatively, the pain of being an outsider impelled conversos toward a psychological and epistemological breakthrough, allowing them to see as ludicrous or flawed an Iberian social, religious and political order that Old Christians took for granted. Living in the orbit of the Inquisition, conversos were not able to express their original insights openly; rather they expressed them in ironic hints, in sly literary allusions, or in the valorization of an interior life that was not governed by rigid social codes. Once conversos left the Ibe- rian Peninsula and were able to breathe the freer air of Bordeaux or Amsterdam, some of them, conditioned to an independent outsider's viewpoint, became radical critics of accepted political, philosophical, and religious notions.

One of the key aspects of the "converso sensibility," as portrayed in this literature, is a subjective perspective. As one author put it, "the procedures of the Inquisition, the conversions and theological investigations into ancestry, origin, and affiliation" were preconditions for "the constituting of subjective consciousness." (Zepp, 2014: 12). Without getting too deeply into a complex philosophical issue - scholars have developed entire theories of subjectivity - let me suffice with the definition offered by Nick Mansfield in his work Subjectivity: Theories of Self. Subjectivity, he wrote,

is primarily an experience, and remains permanently open to inconsistency, contradiction, and un-selfconsciousness. Our experience of ourselves remains forever prone to surprising disjunctions that only the fierce light of ideology or theoretical dogma convinces us can be homogenized into a single thing. (Mansfield, 2000: 6-7)

An everyday example may bring this closer to earth. Suppose a native of New Delhi visits New York and takes a group tour. The tour guide offers a cheerful, neatly constructed narrative following a time-tested formula, speaking of New York as a certain "thing" with such-and-such characteristics and such-and-such a history. But the visitor's own experience of New York - a shifting and chaotic array of emotions, observations, and sensations - is quite different. To the degree that the visitor is aware and can articulate the discrepancy between the professional narrative she is hearing and her own inner experience, she has developed a "subjective consciousness."

An awareness of our own subjectivity - a perception of the messiness and incoherence of our inner lives - can emerge only when we have escaped fixed notions of identity and self which have been imposed from without. Scholars believe that a starkly new awareness of inner consciousness was triggered in various ways and in certain people by conditions in early modern Europe. ${ }^{2}$ Early modern Iberia is not usually on the radar screens of scholars who study subjectivity (or for that matter any aspect of European modernity). But for certain scholars of Jewish modernity, for whom subjectivity is an important aspect of "Marranism," it has become a singular focus of attention. ${ }^{3}$

Yirmiyahu Yovel, the standard-bearer for the current "Marranism" literature, offers the following description of the mental process by which subjective consciousness emerged among the conversos. After the Jews were expelled from Spain, Yovel writes,

[t]he Judaizers became increasingly lonely and secluded, depending more on the resources of their own solitary selves - on memory, hope, vision, and personal conviction. For them authentic religion had been deinstitutionalized and privatized - not merely in the sense that it was concealed inside the home, but also of depending on the inner heart as its almost sole support.... 
In the end, and all along, the person had to face the most important religious truths - decisions about value, and about personal fate in this and the next world - within a private "inner forum." Thus emerges the Self-or human subjectivity - hesitantly and, again, in stages: first as the locus of true religious worth; then as the judge and bearer of value in general; and later, as the object of self-affirmation and of self-investigation and exploration. These are all hallmarks of modernity..., of which the Marrano experience injected important rudiments into Renaissance Spain and early modern Europe (Yovel, 2009: 88)

Yovel's depiction of crypto-Jews and conversos as lonely truth-seekers who independently discovered the "self" and thus helped lay the foundations of modernity is very much open to criticism. ${ }^{4}$ Unfortunately, it reflects problems present in the "Marranism" literature as a whole. The great majority of conversos, whether they were crypto-Jews or not, were not lonely, self-aware truth-seekers; most of them lived in a rich collective domain of family and community. The ex-converso Isaac de Pinto, for example, scion of a prominent converso family, wrote a family history that is a model of loyalty to inherited values and unselfconscious traditionalism. ${ }^{5}$ To be sure, some conversos were radical truth-seekers; however, in the early modern period lonely, self-aware truthseekers could be found all over Europe. It is simply not true, as some imagine, that Iberian lands were sealed off from innovative currents of thought developing on the other side of the Pyrenees; nor did such currents somehow bypass Old Christians. The many intersecting pathways of unconventional thought in this period throw doubt on the very possibility of any specifically converso discovery of "the Self." The many converso alumbrados of Spain may have been stimulated by their difficult converso situation to search for understanding within; but the evidence is abundant that they were also inspired by contacts with northern Erasmians and Italian humanists. ${ }^{6}$

A further problem in the Marranism literature is its acceptance of the early modern Iberian, racially-determined status of "converso"; it is contradictory to argue that a "converso sensibility" was situationally determined and then to discover it in people far removed from anything that might be called "the converso situation." Montaigne is a case in point. The Marranism literature frequently links Montaigne's extraordinary exploration of subjective consciousness to his maternal grandfather's converso origins - surely an extreme and perverse explanation for the powerful insights of this aristocratic native of France, who may or may not have known of those origins. ${ }^{7}$ And finally, looking at the issue from a somewhat different perspective, the argumentation of the Marrano literature fails to register the fact that although conversos and exconversos were dispersed across great geographic expanses, the phenomenon of "Marranism" was confined to Europe. There is a reason why we are not surprised to find Spinoza the Portuguese Jew in the Netherlands rather than, say, in Izmir or Istanbul: Europe was the site where the synapses that produced "modernity" were sparking. ${ }^{8}$
There are other weaknesses as well in the literature of "Marranism." The ironic, positive spin given to the term "Marrano" in this literature - a term that has all but disappeared from historical research on conversos - signals a discourse in which that term means something other (and more) than "converso." Some authors who use "Marrano" in this way say quite explicitly that they are using it as a metaphor. ${ }^{9}$ Others, however, see conversos (or rather, a certain set of converso intellectuals) as their own ideological ancestors. This is bound to skew the results of their research. Searching for the "Marranic" in works by known converso authors means the "Marranic" will be discovered; conversely, if an author betrays "Marranic" characteristics, it is evidence of his Jewish ancestry. The image of "the Marrano" that emerges looks very much like the image in the mirror.

Yet while this kind of scholarship may fail to prove that the converso situation was the sufficient cause of early expressions of subjectivity among conversos, it doesn't disprove that this situation played a role. It remains a startling fact that Spain's "Golden Age," with its brilliant explorations of the subjective, is unimaginable without authors of Jewish ancestry. One need only mention the names: Luis Vives, Luis de León, Teresa de Ávila, Juan de Ávila, Juan de la Cruz, Juan and Francisco de Vergara, Juan and Alfonso Valdés, Francisco de Vitoria, Francisco Sánchez, Andrés Laguna, Fernando de Rojas, Mateo Alemán, Luis de Góngora. The conspicuousness of converso authors during this burst of creative activity begs the question, Did converso intellectuals tend to think more "modernly," more subjectively and subversively, than other Spaniards? If so, can it be explained by their particular condition?

The earliest scholar to try to make sense of a distinctive converso inclination to "subjectivity" was - to return to the subject of this essay - the Spanish philologist and thinker Américo Castro (1885-1972), who produced his work in exile, mostly at Princeton..$^{10}$ His studies, culminating in the 1962 edition of his La realidad histórica de España, are cited frequently in the literature of "Marranism." Yet Castro's project was quite different in its aims and presuppositions from the recent "Marranism" scholarship. Although conversos played a major role in Castro's historical imagination, they were not in themselves a primary subject of interest. His aim was, as he put it in one of the various iterations of his magnum opus, "the clarification of that perplexing problem of who the Spaniards are, how they are made up, and their ultimate worth as a nation." (Castro 1971: 583) ${ }^{11}$ Castro's lifelong task of rethinking Spain's history arose in the context of efforts among Spanish intellectuals to come to terms with what they saw as Spain's national moral, social, and political decline - a decline that seemed undeniable after the loss of Spain's last imperial territories in 1898, although the theme had been present in Spanish discourse much earlier. ${ }^{12}$

Castro's historiographical approach reflects anti-positivist, romantic currents that were in the air during his 
training as a philologist (in Spain as well as, more briefly, in France and Germany). ${ }^{13}$ Following Wilhelm Dilthey in particular, Castro believed intuition and empathy were among the scholar's most important assets. The challenge in determining "who the Spaniards are" was capturing, the way an artist grasped a subject, in a holistic, organic way, the living spirit of the Spanish people. ${ }^{14}$ It was in this romantic vein that he developed his twin ideas of the morada vital of a people - that cluster of characteristics that makes up the unique "nosotros" of a people - and the accompanying concept of vividura, or the consciousness of a people of being part of that collective existence. ${ }^{15} \mathrm{He}$ wrote Spanish history, he said, "almost as a confession, a biography, without following strict 'academic' criteria." (Castro, 1949: 234)

While Castro drew conceptually from German and French intellectual descendants of Hegel for his approach, his enterprise was a Spanish one shaped by his immediate environment. In the early decades of the twentieth century not only he but virtually everyone around him was pondering the issue of Spanish national identity and selfimage. This was an intrinsic aspect of intellectual life at the Centro de Estudios Históricos in Madrid, where Castro entered into conversation with the philologist Ramón Menéndez Pidal and the Arabists Julián Ribera and Miguel Asín Palacios. ${ }^{16}$ These men, heirs of the Generation of '98, saw a need for a Spanish self-transformation that would restore Spain's sense of dignity in the world. But while Castro's interest in developing new foundations for Spanish identity was one he shared with contemporaries, and while his work should be evaluated alongside theirs, his work stands out for having made a mark outside of Spain, engendering sharp polemics while also inspiring a generation of North American Hispanists. Among the latter, Castro's student Stephen Gilman was particularly important in creating a bridge between Castro's work and the later "Marranism" literature. ${ }^{17}$

\section{$* * *$}

To properly frame and evaluate the topic of this essay - Castro's treatment of the issue of subjectivity and the conversos - it will be helpful to see where this topic fits within the contours of Castro's work, especially since his prolix, time-collapsing and often self-contradictory mode of exposition makes it difficult to discern the logical scaffolding beneath it. The task is also complicated by the fact that Castro's thinking changed somewhat over the twelve years of his frenetic work between 1948 and 1962.

The starting point is 711 , when the major players in Spanish history - the three "castes" - were thrust together by the Muslim conquest of Spain. "Caste" is a key term in Castro's work, one he insisted (not always convincingly) that he used to refer to lineage but not to biological race. ${ }^{18}$ While religion was the most obvious marker of difference, it was only one of several intertwined characteristics distinguishing each caste, among them language, occupational preferences, and emotional disposition. For Castro, relations between the castes, in the early period more-or-less peaceful but later deeply fraught, ultimately determined the shape "Spanishness" would assume.
Castro's vision was not formed ex nihilo. It reflected his training in philology and some of the dominant concerns of that field in nineteenth- and early twentieth-century Europe. At the time, philologists were occupied with an ambitious project of historical reconstruction, believing their field held the key to unlocking the mystery of the origins and differing characteristics of peoples. By means of a complex process of rumination and comparative study, a consensus had emerged that there existed two fundamental groups of languages, Aryan (or Indo-European) and Semitic. From this basic distinction there emerged a discourse of race, religion, and national origins that escaped the confines of the academy and became part of popular lore. Aryan peoples were heirs to the abstract, analytic intellectual gifts of the Greeks; they excelled in science, technology, and the arts. The Semites, in contrast, possessed languages that better expressed the sublime, the sensual, and the emotional; this orientation explained their stubborn clinging to a monotheistic faith. ${ }^{19}$ For Europeans reveling in their own accomplishments, it was evident who was superior.

Certainly in Spain, the picture was far more complex. For Spanish scholars, the discourse of "Occidental" and "Oriental" difference was complicated by the fact that "Semites" were so deeply entangled in the Peninsula's history. Jews were less conspicuous in the overall conceptualization of Spanish history, since they were a minority without territory or political power, and could be found elsewhere in Europe. Muslims, in contrast, had ruled much of the Iberian Peninsula for centuries. Given the widespread negative image of Muslims - they were backward, barbaric, ignorant - there was a tendency to see the medieval period of Spanish history as an aberration, a disastrous historical anomaly that warped the "natural" course of Spanish (i.e., Christian/"Occidental") history. Centuries of Muslim domination might even explain the other great disaster of Spain's history, its decline visà-vis the rest of modern Europe. Castro's great opponent Claudio Sánchez-Albornoz argued that the Spaniards were a great people to have survived Islam as well as they did; were it not for Islam, they might be the leaders of Europe. ${ }^{20}$

The problem that medieval Muslim domination of Iberia posed for Spaniards as they sought to establish a shared national narrative was somewhat mitigated by a romantic European literature that exoticized and idealized medieval Spain - a land of knightly virtues shared by Christians and Moors. This image was popularized by foreign authors with a romantic inclination - among them Lord Byron, Washington Irving, Victor Hugo, Alexandre Dumas, and Prosper Merimée. The theme was picked up by Spanish liberals living in exile in England after the restoration of Ferdinand VII (and through them transmitted to Spain), as well as by a few conservative romantics in Spain in the 1830s and 40s. (Monroe,1970: 59-63 and 68; Junco, 2001: 386-390).

But more important in the long run for the construction of an integrated narrative of Spanish history and a vision of national identity was a circle of Spanish Arabists who 
were reflecting, like other Spanish intellectuals, on the problem of national identity. ${ }^{21}$ Some of them worked at the nerve centers of the intellectual debate over Spanish national identity - the Institución Libre de Enseñanza, a pedagogical project initiated by a group of scholars who broke with the scholarly establishment, and the Centro de Estudios Históricos, a research institute founded in 1910 to modernize and professionalize research on Spanish history and culture. While their views were by no means identical, these scholars shared an appreciation and understanding of Muslim civilization (especially that of al-Andalus), and were able to make the mental leap to an idea of a "Spain" that had been created by both Christians and Muslims. More than a century before Castro's work, the Arabist José Antonio Conde argued that the Spanish romance - and the Castilian language in general - was influenced by Arabic texts. (Monroe, 1970: 56). In an address before the Spanish Academy in 1894, when Castro was a boy of nine, the Arabist Francisco Fernández y González argued for the essentially "Oriental" character of Iberian civilization before the Muslim conquest. (Monroe, 1970: 114-115). He further argued that medieval Spanish clergy were familiar with Arabic, that the Archpriest of Hita had adopted the maqama genre from the Arabs, and that the latter had borrowed some of the stories in his Libro de Buen Amor from an Arabic work. (Monroe, 1970: 115). (Half a century later, Castro returned to this theme.) The Arabists who sought a vision of Spain that included AlAndalus made this idea more palatable to a public for whom Spain was religiously Catholic, ethnically European, and linguistically Castilian by "Hispanicizing" al-Andalus. The term "Spanish Muslims" became the term for the Muslim population of al-Andalus, which in turn became known as "Muslim Spain." Spain became the fertile field on which Arab and European civilizations met. (Marín Niño, 2009: 207; Monroe, 1970: 252-6). "Spanishness" had in some way rubbed off on Spain's Muslims, making them more familiar and distinguishing them from, among others, contemporary North Africans.

There are probably multiple reasons, aside from the challenge posed by Muslim sovereignty in medieval Spain, why Jews figured less than Muslims in progressive visions of Spanish national history in the nineteenth and twentieth centuries. While notable Hebraists were active in the Spanish academy, they were not prominent in the intellectual circles that dominated the conversation about national identity after 1898. (Millás Vallicrosa, 1956: 249-258; Roth 1989, 317-323). Castro noted that while Ortega y Gasset had at least acknowledged the Arab presence in Spain when he stated that they were not an "ingredient" in the history of the Spanish people, he did not even mention the presence of Jews. (Castro, 1971: 64). It does not seem surprising, then, that in the 1970s the Arabist Emilio García Gómez referred to Spanish Arabism as the study of "the complicated Iberian medieval past, with its constant interconnection of two worlds instrumental to understand our culture." 22

Yet Jews did figure in certain scholarly efforts to come to terms with Spain's past, laying some of the ground- work for Castro's scholarly project. The pioneering historian José Amador de los Ríos made the medieval Spanish Jews the subject of two substantial works in the mid-nineteenth century. Although his conception of Spain remained a Catholic nationalist one, and ultimately denied a valid place for Judaism, Amador de los Ríos established as undeniable the role of Jews in Spain's history. (Friedman, 2011). A generation later, the Jesuit scholar Fidel Fita energetically sought to recover Jewish texts and inscriptions - precious elements, in his view, of the Spanish patrimony. But his activity was one of retrieval, not interpretation, and he did not address how (or whether) Spanish Jews figured in Spanish national identity. (Friedman, 2012: 101-136).

Standing out among scholars of this period as someone who anticipated Castro's work was the liberal scholar Francisco Fernández y Gónzalez, who as early as 1861 suggested the importance of a cultural and racial fusion in the process of Spanish national formation, one that included both Arabs and Jews. Fernández y González not only rejected the idealization of racial purity and the myth of a strictly Christian Spanish past, he suggested that because of its racial mixing (which he compared to "the precious grafts of the vegetable world" [Martin-Márquez, 2008: 56]) Spanish culture was superior to the "Hellenic" culture of the rest of Europe. In a further theme that Américo Castro would echo, he maintained that the Spaniards alone among the European nations conserved "the fervor of oriental religious feeling." ${ }^{23}$ While trained as an Arabist, he took an increasing interest over his career in the "judios españoles," whom he hispanicized terminologically and culturally much as Arabists had hispanicized Spanish Muslims. (Friedman, 2012: 177).

In the post-1898 era, with its elite's neo-colonial aspirations and preoccupation with national "regeneration," a number of Spanish intellectuals took up the theme of Jewish-Spanish racial mixing. Their interest was contemporary and political, but it implied a reinterpretation of the past. The physician and senator Ángel Pulido y Fernández, who campaigned to repatriate Sephardic Jews in Spain, saw the continued use of Spanish among the Sephardim in the Balkans and Morocco as evidence of a common Spanish-Jewish spiritual community, and held that racial mixing among Spaniards and Jews had produced a visible racial affinity. In a way that echoes claims about hispanized medieval Arabs, Pulido maintained that the mixing of the Sephardim with Spaniards had rendered them superior to other Jews. (Rohr, 2011: 63-66; Goode, 2009: 184-206). Américo Castro’s protégé Ernesto Gimémez Caballero, among others, expressed similar enthusiasm for a reinvigorated "greater Spain" that would reintegrate the Sephardim into Spanish culture (Friedman, 2012: 212-243)

Américo Castro, in his effort to create a grand new vision of Hispanidad - an aim he pursued after 1936 in exile in the United States - drew from the various ideas these scholars, among others, had developed. But he departed from them emphatically in two ways. First, while he placed ethnic fusion at the heart of a master narrative 
of Spanish history - a narrative that extended from antiquity to the modern period - he shifted Spain's "golden age" from the medieval to the early modern period. Second, he adopted an elusive overarching idea of national "essence," one that relied on intuition to discern, and literary skill to convey. Spain's morada vital, or way of being, was forged, he argued, by an ever-changing relationship among Spain's three "castes" - Christians, Jews, and Muslims. This was not just a process of cultural exchange that produced "hybridity" (though it was that, too); more profoundly, it was the unconscious collective shaping of an outlook on life. In a twist, Castro asserted that Spain's particular morada vital came to its fullest expression in a set of sixteenth- and seventeenth-century works of literary genius, all of them reflecting a breathtaking grasp of subjective experience and all of them written by descendants of Jews.

There is no reason to believe that Castro did not enjoy the shock value of this thesis. He thrived on controversy, and rarely hesitated to overstate his points for polemical effect. By giving "Jews" pride of place in the cultural expression of Hispanicity, he was going far beyond other enthusiasts of Spanish cultural/racial fusion. He was of course aware in the 1940s, when he was working on his España en su historia, that Jews were being seen as pollutants of national cultures in an unprecedented way. He may have associated this "sanitized" notion of identity with the delusional thinking, as he saw it, of Spanish conservatives who promoted a vision of an eternal ChristianGothic Spain. In any case, Castro found an apt symbol for his organizing idea of the three castes in the tomb of Ferdinand III located in the cathedral of Seville, with its inscriptions in Latin, Castilian, Arabic, and Hebrew. ${ }^{24}$

Castro is well-known (perhaps best known) for having painted a rather rosy picture of medieval Spanish convivencia, in which the three castes lived in a mutually fruitful relationship. This representation of medieval Spain has played a role in inspiring books and exhibitions aimed at rescuing us from current tensions involving the Muslim world. But such multicultural celebrations do not accurately reflect Castro's thinking, which betrays a profound ambivalence, at least about Jews. In fact it is fair to say that two different perceptions of Jews exist uneasily side by side in Castro's work, which for convenience I will call the "oriental" and the "Jewish." This bifurcated perception has important implications for Castro's analysis of converso "subjectivity."

Much of the time, Castro conflated Jewish and Arabic characteristics in a generic type that he called "Semitic," "Oriental," or "Hebrew-Islamic" - terms he used interchangeably. ${ }^{25}$ In this respect, Jews and Arabs were equally endowed with "oriental" imagination and emotion. The "semite" was acutely aware of emotional and sensory experience, of the flow and mutability of existence. It was a "Semitic tendency" to "speak about the real and concrete from a personal, intimate point of view." (Castro, 1971: 151) There was an erotic earthiness in "semitic" descriptions of nature; as Castro put it, "the sexual sublimation of the earth...shows the stamp of Islamic-Judaic thought and feeling." (Castro, 1971: 161) (“Oriental" characteristics of this kind had been described as early as the late eighteenth century by the renowned philologist William Jones [Regueiro Salgado, 2013: 192]), and are evident in later European efforts at "oriental" writing. ${ }^{26}$ ) The semitic peoples also had a special gift for religious expression and awareness. The westerner (i.e., European), in contrast, excelled in rational analysis and speculation. (Castro did admit that Muslims had been superior to "westerners" in science and philosophy for a certain period, but did not let this anomaly detain him.) In its formative preReconquista period, according to Castro, Castile had been "occidental" and thus incipiently "European" (though feebly so). ${ }^{27}$ After the Muslim invasion, however, it became fatefully intertwined with the "oriental" due to increasing Castilian contact with Jews and Moors. This produced a Spain that was "a mingling of Occidental and Oriental ingredients" (Castro, 1971: 125) - neither a total disaster nor a blessing, but a historical reality.

There is no doubt that Castro's work suffers from the flaws and limitations of an essentialist analysis - one that relies on stereotypes, heavy-handed generalizations, and questionable assumptions. ${ }^{28}$ Yet Castro was by no means slavish in his idea of the "oriental"/"semitic" in his vision of Spanish history. And this gets us to the characteristic of his "orientalism" (and thus of his "Hispanicity") that concerns us - that of "subjectivity," a characteristic that as far as I know has no place in classical orientalist discourse. Castro's discussion of this theme is most detailed in his España en su historia, but it is apparent throughout his work.

Castro maintained that there was an "almost total absence of subjective expressiveness [expresividad subjeti$v a]$ (either religious or literary) in Castile before the fourteenth century." (Castro, 1954: 315) ${ }^{29}$ As was his habit, Castro nowhere defined what he meant by "subjectivity." Rather he informed the reader with long descriptive passages of what he meant. The lack of erotic poetry in early Castile he explained this way: "Any effort to express intimate feelings would have drawn the austere soul of Castile toward modes of free-ranging sensibility that would have endangered the stability that soul had developed." (Castro, 1954: 321). In contrast, the "oriental" way of being of Muslims and Jews meant that they freely embraced the subjective. The tendency "to speak about the real and concrete from a personal, intimate point of view" was a "Semitic tendency" - a Hebrew-Islamic, oriental inclination - already recognizable in the Hebrew Bible and the Koran. (Castro, 1971: 151. My emphasis.) For Castro, it was the late medieval integration of the Castilian view "from without" with the Muslim view "from within" that determined the course along which a unique "Spanishness" emerged. (Castro, 1954: 344)

Even at this point we can see that what Castro meant by "subjectivity" was multifaceted. At times, it seems to mean primarily a lack of inhibition, an openness to passionate emotion of all kinds. At others, it seems to signify an awareness and grasp of immediate felt experience that is antithetical to an analytical, empirical, theoretical, "Oc- 
cidental" grasp of reality. (This might be manifested, for example, in Arabic or Hebrew lyrical poetry that captured the immediacy of a moment, a place, a sight or a smell.) But "subjectivity" could also mean interiority of consciousness, a way of living in the solitude of one's own mind - a meaning that comes closest to that developed in the Marranism literature.

Following the general rule that we define ourselves against the "other," Castro frequently illustrated his claims by comparing the "orientalized" Spanish to a venerable Spanish "other," the "occidental" French. Castro observed that French authors had written memoirs that "focused on what happens around the life of the author" (my italics), while the Spanish had produced autobiographies in which "the writer presents himself as existing in the privacy of his own consciousness." And he continued:

The autobiographical thread which runs through [Gonzalo de] Berceo's poetry is spun from Islamic wool. In this connection I have in mind the Book of Job, the Confessions of Saint Augustine-a Semite, ${ }^{30}$ Islamic confessions and autobiographies, Saint Teresa's Life, Lazarillo de Tormes, Guzmán de Alfarache, etc. French classic literature is as rich in memoirs as it is poor in authentic confessions. The autobiography of Guibert de Nogent, De vita sua, of the end of the 11th century, which has more than one oriental feature, seems rather exceptional. As for Montaigne's Essais it should be kept in mind that his mother was a Spaniard of Jewish extraction. (Castro, 1954: 361)

Similarly, Castro contrasted the French Roman de la Rose with the Libro de Buen Amor of Juan Ruiz, also known as the Archpriest of Hita:

Those acquainted with the Roman de la Rose...can measure the distance between its deliberate rationalism and Juan Ruiz's vitalism [that] evolved in the constant reversals of an existence fraught with difficulties, in the continual oscillation between longing and frustration. The Libro de Buen Amor does not fit within the bounds of didactic poetry, where life is contemplated from the outside, set between parentheses and viewed in the stable, ideal reality of the ought-to-be, not in the problematical reality of its existence. (Castro, 1954: 397)

The "subjectivization" of the Castilian way of being was, for Castro, a historical development - a medieval one - that occurred in part because of the inability of Christian Castilians to form "a dwelling place with secure occidental foundations." (Castro, 1954: 372) As he put it,

[B]efore subjectivism of literary expression could exist, the barrier of inhibitions that kept the Castilian inwardness shut off and silent had to disappear.... The fact that in the fourteenth century, prose begins to express the inner reality of a person who himself appears in the prose and speaks for himself is a phenomenon contemporary with the lyricism of the Archpriest of Hita and the poetry of the Jew Santob of Carrión....All this is inseparable from the totality of Castilian history after 1300. Because Don Juan Manuel gave free rein to his inner self, some- thing that had not gone on before, it was possible for him to go beneath the surface of other lives and tell us what he found there. (Castro, 1954: 385-6)

And again (with the reader's indulgence), a few pages later on, the same development:

That which has been public becomes private and personal, and the way is thus prepared for the Romancero in the fourteenth century, for lyric poetry and the authentic novel....But the essential point here is that the earliest germs of the novel came into existence in Spain accompanied by the personal expression of an "I." This is what has led me to write elsewhere that the lyrical style of the pastoral novel and even the style of the Spanish mystics played a dominant part in the historicoliterary gestation of the Quijote. And at the deep center of such complexities one can hear the echo of oriental tradition, the beat of "the atom of my heart" which [Mansur] Al-Hallaj has told us about. (Castro, 1954: 387)

Castro not only embraced the infusion of "oriental" patterns into Castilian life; he expressed a degree of distaste for the "occidental" mode of existence, as manifested in French culture in particular, but in rational/industrial modern societies in general. Despite impressive achievements, the West lacked something of human vitality. It lacked the Sturm und Drang, the struggle, the melancholy and the anguish that Castro associated with the oriental cast of the Spanish soul..$^{31}$ This kind of defensive denigration of French rationalism by Spaniards was not original; it had roots in resentment about France's eighteenth- and nineteenth-century aggressions against Spain, and was part of the contemporary discussion of what distinguished Spain from the rest of Europe. Castro's very style of writing was meant to express the amplitude of Spanish vividura. Let me quote a rather lengthy passage by way of illustration:

[I]n Cervantes (and in the aforementioned text of [Abu Bakr] Ibn 'Arabi) we find an awareness of inner existence as unique and complete (consciousness of self from within as a totality embracing the exterior world)...This is the vital course on which destiny set the history of Spain, determined to act "with her whole being," in the personalized and peculiarly Hispanic fashion that I have previously analyzed. This course of ambition and anguish has been taken by Spain in her greatest ventures as well as in her most wretched failures, for to live to the utmost - vivir viviéndose - is not separable from living in agony-vivir desviviéndose. And having adopted this perspective, I find that I have a better understanding of Don Quixote and Sancho Panza, the life of Saint Teresa, and the life of Lope de Vega; and I believe that in general such a perspective makes possible a more accurate perception of the meaning of the phenomena which in modern times have been ineptly called Hispanic realism or individualism. (Castro, 1954: 344-5)

It is true that seen in isolation from his overall structure, Castro's description of the subjectivity of converso 
authors like Santa Teresa, Luis de León, Luis Vives, Juan and Alfonso Valdés, Francisco Sánchez, Fernando de Rojas, and the author of Lazarillo often sounds closely related to modern notions of "subjectivity." We can hear it in his description of what he described as the greatest conquest of Cervantes, whom Castro believed was a converso, namely "the discovery of the awareness of human consciousness, a consciousness enriched by all the literary experiences of the inner self provided by the sixteenth-century Spanish writers." (Castro, 1971: 146-7) Such passages resonate with the discourse of Marranism, at least to the degree that Castro saw the formation of an inwardly sensitive converso consciousness as a reaction to a situation of oppression and injustice. And he did see a connection between the experience of oppression and the gestation of subjectivity. The spirituality of the sixteenthcentury Spanish Erasmists, he maintained, was not an importation from the north (as Marcel Bataillon would have it) but a continuation of the spirituality of fifteenth-century conversos, "those who had sought the quiet solitude of the heart." These men and women searched within for justice and tranquility, "since all external manifestations - whether of the law, the princes, or the rancorous masses - offered no guarantee of justice." (Castro, 1971: 330331) What Castro called "el adentramiento en la propia alma" intensified among conversos as pressures on them increased from without. (Castro, 1971: 330) To be sure, most people were intellectually and morally incapacitated by the repressive climate of early modern Spain. But, he wrote,

there were others who opted, not to objectify their thoughts (a dangerous exercise), but to place themselves at the center of the conflict without experiencing a breach between existing and thinking. Since it was licit neither to speak nor stay silent without great risks (as Luis Vives wrote to Erasmus), there remained, as a way out, making manifest the very situation in which one felt oppressed and limited. And thus it happened that the very closing in of one's environment made possible the clarities and openings of literary expression. The same anguish that...prevented Luis de León, Francisco Sánchez, and Sor Juana from expressing themselves in public - this same narrowing of horizons indirectly made possible the art of Teresa of Jesús and Cervantes. (Castro, 1961: 190. My translation)

The path connecting Castro's thinking about converso subjectivity to Yirmiyahu Yovel's would seem to be evident. ${ }^{32}$ Yet the two discussions belong to different universes of discourse. For Castro the "subjective" perspective had nothing to do, strictly speaking, with incipient modernity; it entered Castilian culture not with the early modern influx of converted Jews, but much earlier, with the Muslims and Islamized Jews, resulting in what he called "literary mudejarism." (Castro, 1954: 310) It was the medieval Spanish Jew, "linked with the HispanoMoslem tradition," who had created a vision of man "as a vital, shifting, and changing reality, rather than as a being ontologically one and abstractly conceivable." (Castro,
1954: 573) The "special character of the literature and thought of the Hispano-Hebrews" was, Castro wrote, "closely connected with an inclination to express those things experienced in the depths of their anguished consciousness." (Castro, 1954: 571) ${ }^{33}$ Thus, the potential existed long before the fifteenth century for the anguished converso consciousness of the sixteenth and seventeenth centuries.

In explaining converso behavior, here as elsewhere, Castro constantly toggled between mysterious, ancient and unexplained Jewish impulses (he repeatedly stressed that he did not mean biologically determined ones), on the one hand, and situational historical explanations, on the other. The basic dynamic was this: Archaic and seemingly fixed "Jewish" or "Semitic" qualities surfaced in new ways in early modern Spain, revitalized in the conversos by a unique conjuncture of circumstances (Inquisition, discrimination, stigma).

Castro's underlying idea of the rekindling of archaic patterns is basic to his thinking about conversos; he was not fundamentally a "situationalist." This conception extended even to the bitterness and despair he perceived in converso literature. A "gloomy" outlook on life was, he maintained, "a familiar theme in the Jewish tradition." (Castro, 1954: 559) It was embedded in the Jewish outlook from time immemorial. ${ }^{34}$ To demonstrate this (in a good example of the more dubious aspects of his working method), he cited a single brief passage from the Hebrew Bible - "a Semitic work par excellence": "And it repented the Lord that he had made man on the earth, and it grieved him at his heart. And the Lord said, I will destroy man whom I have created from the face of the earth." (Castro, 1954: 576, citing Gen. 6: 5-6) The conversos' painful circumstances played a role in producing their dark mood. If Fernando de Rojas's great work reflected a "tragic sense of life," it was because "the life in which it was incubated and brought to birth" - that is, Rojas's life as a converso - was tragic. (Castro, 1954:564) Yet beneath immediate circumstances lay something more primordial. Hovering ambiguously between the primordial and the situational, Castro summed up this way: "The Spanish convert of the fifteenth and sixteenth centuries expressed himself in somber modes because circumstances drove him back to the deepest roots of his own existence." (Castro, 1954:567. My emphasis.)

This representation of the particularity of converso subjectivity stands somewhat at odds with Castro's representation of early modern Hispanicity. By the sixteenth century, he maintained, a subjective perspective had become culturally dominant in Spain. Once unleashed in Spanish society, the "desperate style of the Judaic tradition" became "a possible form of expression for many Old Christians" as well. (Castro, 1954: 568) Indeed, Castro noted that the medieval Hebrew poet Shem Tov ben Isaac Ardutiel had talked "in a language that anticipates Sancho Panza's wisdom," taking as his point of departure his "own awareness of vital experience" - adding, to underscore his point, "this sounds very Spanish"! (Castro, 1954: 574. My emphasis.) Likewise, he wrote that the 
New Christians, "being Spaniards, sensed the importance of the self." (Castro, 1954: 570. My emphasis.) Only this existing orientation to the self in Spanish life could explain, for him, the great burst of literary brilliance of the sixteenth and seventeenth centuries. "Since, for the Spaniard, whether or not of Hebrew descent, there actually was almost no authentic world beyond that of his own self, it is understandable that the trend of oriental life should find fertile soil in Spain and achieve a strong growth - in the Celestina, in mystical writings, in the picaresque autobiography, in the drama, and in the Cervantine novel." (Castro, 1954: 575. My emphasis.)

This begs an obvious question. If Spanish culture in general had become "subjectivized" by the early modern period, why did conversos in particular come to occupy such a disproportionate place in Spanish Golden Age literary production, with its brilliant subjectivities? Castro's answer to this question requires looking back at sociological developments in late medieval Castile. While Castilians had busied themselves with war, Jews had assumed roles in occupations that called for technical knowledge, such as administration, commerce, and medicine. Beginning with Alfonso X, Castilian monarchs sought to develop a brilliant court life; but Spanish Christians, conditioned to a role in conquest, were unable or uninterested in this enterprise. In contrast, the many Jews who fell under Christian rule during the Reconquest were perfectly poised to serve Castilian monarchs in this fashion, having absorbed Arabic learning under Islam (without, in Castro's view, having made a creative contribution of their own).

At this point, it may be useful to return to the split in Castro's thinking between "semitic" characteristics, shared by Jews and Muslims, and strictly Jewish characteristics, which reflected classical anti-Jewish discourse. His ambivalence about (Jewish) Semites is reminiscent, mutatis mutandis, of conflicts about Jews within the wider European debate about race - conflicts that had their source in a much older theological discourse. ${ }^{35}$ For Ernest Renan and others, the Jews, with their spiritual genius, gave the world the gift of monotheism. But at the same time (and here the imagery is from Paul), they existed as a desiccated branch on the trunk of revealed truth, unable to take the great historical leap into Christianity. ${ }^{36}$ Castro's ambivalent view of Jews has led to his work being evaluated in strikingly contradictory ways - as either progressively pluralistic or suffused with hidebound stereotypes. $^{37}$

Castro was not a religious propagandist, yet it is hard to understand his recurrent depiction of Jews as lacking in creative abilities - or as uninspired except by opportunism - except as reflecting deep-seated Christian ideas about the Jews' historical role, ideas that had been given fresh expression by Renan and other racialist thinkers. Christianity was victorious, Renan wrote, only after it "completely broke out of its Jewish shell" and became "free from the narrow bonds of the Semitic spirit." While Christianity was "originally Jewish to the core," it eventually "rid itself of nearly everything it took from the race, so that those who consider Christianity to be the Aryan religion par excellence are in many respects correct." (Olender, 1992: 70) ${ }^{38}$

Clearly, Castro did not follow this line of reasoning in its specifics. He was a fierce opponent of the neo-Catholic vision of Spain adopted by political conservatives, with its unvarnished Christian triumphalism. Yet he apparently did not entirely escape the imprint of an age-old historical vision in which Jews represented a hostile element. Castro's willingness to blame Jews for the most intolerant aspects of early modern Spanish society is especially telling. He maintained that the origins of early modern Spanish religious and racial intolerance were in the alja$m a$, the medieval Jewish community, and were transferred by early Jewish converts into a previously tolerant Christian society. The persecutory impulse of the converts was responsible for producing a) the Inquisition, ${ }^{39}$ b) the obsession with lineage and "purity of blood," c) a preoccupation with external honor and status. ${ }^{41}$ This position was not original with Castro; it had been adopted by Menéndez Pelayo in 1887 and by others subsequently. ${ }^{42}$ Such a claim served an apologetic purpose for Spaniards who saw the Inquisition and the obsession with purity of blood as the reasons for Spain's decline. But it is harder to understand in the thinking of a man who wanted Spaniards to face "historical reality." As Révah wryly pointed out, it was the papacy that had created the procedures of the Inquisition, long before Spain had a converso population. (Révah, 1967b: 15)

Negative "Jewish" (as opposed to "semitic") qualities are evident in Castro's thinking about an earlier episode as well: the Jewish transfer of Muslim culture to medieval Spain. Here as elsewhere Castro marshals the stereotype of the Jew as rapacious and power-hungry. Since in Castile "learning was meager," a Jew "need[ed] only to say or write something about Islamico-Jewish culture in Castilian (as much his language as Arabic), and he put himself in a dominant position." (Castro, 1954: 477) In this transfer of culture, the Jews" "brokerage services thus had a unique market, as they had had all along in commerce and the administration of finance." (Castro, 1954: 485) Yet in the end, these "brokerage services," however soulless and derivative in his view, were invaluable: "Castilian came into use as an instrument of high culture thanks to the Jews who surrounded Alfonso $X$ and excited his extremely refined curiosity." (Castro, 1954: 490) The contrast between the earthbound Jews and the nobleminded king could not have been clearer. ${ }^{43}$

It is striking that Castro sweepingly dismissed the rich intellectual tradition of Spanish Jews in the medieval period. This was a way, perhaps, of camouflaging his lack of knowledge about rabbinic tradition; but, as suggested above, it may well also have echoed age-old supersessionist notions. ${ }^{44}$ In any case, given such an opinion, Castro needed to explain why Jews were nevertheless so heavily represented in intellectual pursuits, even after their role as transmitters of Arab culture had ended (indeed up to the expulsion of 1492). This happened, Castro explained, "because no class with intellectual curiosity" 
existed in the Christian milieu. The great Christian lords patronized Jews as astronomers, emissaries, translators, and so on, in tasks these lords came to see as fitting only for a subject people. ${ }^{45}$ The perpetuation of military values among Spain's royalty and nobles thus created an opening if not a niche for Jews in bookish pursuits. This occupational pattern persisted even after the mass conversions and the expulsion of the Jews. The converted Jews and their descendants continued to be active in the intellectual activities cultivated by their forebears. Old Christians of rank continued to see these pursuits as incompatible with their aristocratic vocation. Moreover, the concentrated presence of conversos in intellectual occupations hardened Old Christian contempt for such work, since it was now associated with tainted blood.

Still, all of the above did not provide a sufficient explanation, in Castro's view, for the conspicuous place of conversos in Golden Age literature. Another element was needed. It, too, like the Oriental style and Jewish exposure to persecution, went back centuries: namely, "the Jews' conspicuous cleverness." (Castro, 1954: 571) That is, as Castro explained, "[w]ithout the Hispanic Jew's ability to express the phenomena of the consciousness effectively," such a literature would not have been written, regardless of other factors. (Castro, 1954: 571)

Castro seemed aware that he lacked a way that was consistent with his caste theory to explain how the uncreative Jewish intellectuals of the medieval period (as he saw them) gave rise in the sixteenth century to the brilliant converso thinkers without whom the Spanish Golden Age would be inconceivable. He reported this extraordinary development simply as fact. In the sixteenth century,

[t]hose people of Jewish descent who aspired to stand out in some way begin to write philosophical, scientific, and spiritual works superior to those written by their ancestors, who had been more outstanding as transmitters of culture rather than creators of original thought or works of significant literary value. Before the expulsion few Jews had reached the intellectual or literary heights of their descendants such as Luis Vives, Gómez Pereira, Francisco Suárez, Luis de Leon, Francisco de Vitoria, Huarte de San Juan, Cervantes, or Góngora. (Castro, 1971: 574-575)

Here and elsewhere in Castro's work, the assimilated conversos after the first generation lacked the negative traits he perceived in the medieval Jews and in the first generation of converts (bearers of the intolerance of the aljama). These later conversos seemed to have inherited the Jews" "oriental" qualities but not their specifically "Jewish" ones. Not only had they become entirely "Spanish"; they had given Hispanidad its most perfect expression.

Recalling Renan's solution to the problem of the Jewish origins of Christianity (that is, the Aryanization of Christianity), as well as the Spanish Arabists' solution to the problem of centuries of Muslim rule (that is, the Hispanization of the Muslims of al-Andalus), one might wonder if a similar dynamic were not at work with Castro in the Hispanization, so to speak, of the pantheon of Golden Age writers, virtually all of whom, in his view, were descendants of Jews. While they retained the "oriental" qualities that for Castro were an integral part of the Spanish morada vital - in their tragic sense of life, their grasp of inner consciousness, and their powers of literary expression - they were free from the extreme intolerance, the soulless opportunism, and the lack of creative aptitude of the aljama Jews.

The likelihood that this dichotomization of the literary paths taken by Jews, on the one hand, and conversos, on the other, had its source in negative attitudes to Jews seems supported by a curious outburst of spleen on Castro's part in 1967, directed at the French Jewish scholar I.S. Révah. Castro was responding to an inaugural address Révah had presented in Paris, in which Révah criticized Castro's methods and, more specifically, his approach to the conversos. ${ }^{46}$ One of Révah's criticisms was that Castro effectively ignored the phenomenon of crypto-Judaism among conversos..$^{47}$ Castro's remarks in reply are revealing. "In Israel," he wrote (although Révah was French) "people are bothered by the conversos" - by which he meant non-judaizing conversos - "and take no interest in their work - work that is so fundamental to the lovers of Spanish civilization. The reason is obvious: the Jews, before and after the expulsion (1492), did not excel like writers in Castilian." He added that "certain Jews [today] thus cast aspersions on the exceptionally high literary level achieved by this series of splendid [converso] artists that begins with Fernando de Rojas and extends to Cervantes and Góngora." Further on he added, "CryptoJudaism does not concern me, since, as it happens, no crypto-Jew in Spain created anything that endures today." (Castro, 1967: 1). The judaizing conversos, unlike the others, manifested the same lack of creativity as the medieval Jews.

$$
* * *
$$

What emerges from a close look at Castro's discussion of converso "subjectivism" is less a compelling argument than an effort to maintain an overarching theory in the face of underlying contradictions. Castro argued that by the sixteenth century "subjectivity" had become a Spanish characteristic; if so, why avow (in the absence of hard evidence) that Cervantes or the author of Lazarillo were New Christians? It was likely Castro's fixed idea that Old Christians avoided intellectual activity, along with the stereotype of the converso he had constructed - a figure who possessed innate access to the ancient Hebreo-Islamic "Semitic" subjective mindfulness that led him to identify as conversos several important authors who have no known Jewish ancestors, among them Antonio Nebrija and Huarte de San Juan. In any case, the particular situation of the conversos - their lack of a secure place in Iberian society - was for Castro merely a corollary factor in the creation of this literature. Moreover, while this literature might reflect Jewish/converso anguish (an anguish that spoke to all Spaniards), Castro could not very well argue, as the "Marranism" lit- 
erature does, that it reflected a condition of modern alienation from rooted forms of collective life. He saw subjectivism as playing an integrative function in the creation of a Spanish way of being.

Castro's view of the role of "semitic" subjectivity in the making of a Spanish vividura thus belongs to a quite different discourse than the "Marranic" subjectivity of Yirmiyahu Yovel's modernity. Castro's importance for the Marranism literature is not his overall vision, which is profoundly Spain-centered and little concerned with intellectual modernity. What is important to the Marranism literature is his identification of a set of brilliant early modern Spanish writers whose works do hint at modern subjectivity, his identification of virtually all of them as conversos, and his conviction that their converso identity went far in explaining their subjective insight.

Yet even the situational argument that Castro shares, to an extent, with contributors to the Marranism literature is problematic. It would be a mistake to underestimate the implications for persons living in early modern Spain of having known Jewish (or for that matter Muslim) ancestry. But the conviction that a certain condition shared by conversos provides the key to (or is even essential for) understanding the emergence of early modern literary subjectivity in Spain is of doubtful merit. Human beings respond to their experience in a myriad of predictable and unpredictable ways. Even identical twins grasp life differently. And of course the life experience of someone who happened to have Jewish ancestry was never limited to "the converso experience." Throughout early modern Europe people were exposed to radical ruptures in the familiar structures of life and thought. The collapse of Roman Church authority in much of western Christendom, the clash of revolutionary new doctrines with resurgent old ones, the disorienting discovery of hitherto unknown cultures in the New World, the grinding wheels of imperial commerce - these developments and others had a pervasive impact, shattering the coherent patterns of late medieval life. If such developments played a role in the development of subjectivity among thinkers in England and France - where the Iberian "converso condition" was nonexistent - should we ignore them in Spain?

This is not to say that the Marranism argument is entirely wrong-headed. It seems perfectly likely that some of the situations in which conversos found themselves contributed to the gestation of subjective insights. The point is that there were many other conditions in early modern Europe that fostered subjective thinking and put their imprint on Iberians, whether they had Jewish ancestry or not. It would undoubtedly improve our understanding to see Iberian expressions of subjectivity, with their distinctive features, included in the wider scholarly study of subjectivity. In the same spirit, the study of subjectivity in Iberian lands would benefit by abandoning the singleminded, laser-like focus on the converso experience, and bringing into consideration the more complex spectrum of factors that was at play in transforming European thought.

\section{ACKNOWLEDGEMENT}

I would like to thank Mercedes García-Arenal and Fernando Mediano for their astute and helpful comments on an earlier draft I presented for Project CORPI in Madrid in October 2016, as well as James Amelang for his insightful comments in conversation. I would also like to thank the anonymous reader for his/her comments and suggestions.

\section{NOTES}

1 Something of an exception, in terms of explanation, are works that see Marranism as an outgrowth of medieval Jewish culture in Spain. In 1971 - long before Marranism became a fashionable topic - an article by Sanford Shepherd pointed to a current of Jewish skepticism dating back to the medieval period and identified it as one that would prevail later among conversos: "The skepticism and rationalism of Uriel da Costa recapitulates the philosophical and religious attitudes that were long established in the Iberian Peninsula among the Hispano-Jews and were continued by conversos in various forms, some humorous, some sarcastic, often as jibes directed against the impossibility of rationally justifying such Christian doctrines as the Trinity, Transubstantiation, and Original Sin." (Shepard, 1971: 350). More recently, this theme has been reiterated by Shmuel Trigano (2000: 261-269 and 2012: 295-303).

2 For an introduction to the contemporary discussion of subjectivity, see (Zahavi, 2008; Siegel, 2005).

3 Among the works that have developed the concept of "Marranism," see (Diner, 2007; Ehrenfreund and Schreiber, 2014; Faur, 1992; Ferruta, 2014; Gyssels, 2012; Harst, 2012; Jama, 2007; Kriegel, 1998 and 2002; Lindenberg, 1997; Marks, 1996; Simms, 2005; Trigano, 2000; Yovel, 2009; Wachtel, 2013 and 2007; and Zepp, 2014).

4 Among the critical reviews of Yovel's work, see (Nirenberg, 2009; Melamed, 2011; Bodian, 2010).

5 The work was published by H.P. Salomon (1975).

6 On the complex cluster of intellectual and spiritual currents that the Inquisition identified as alumbradismo, see (Bataillon, 1995; and Pastore, 2010)

7 Yovel went so far as to write of Montaigne that "the Spanish Marranos in the region of Bordeaux gave France... its brightest writer of the sixteenth century." (Yovel, 2009: 328). Among the works that discuss Montaigne as a "Marrano" see (Zepp, 2014: 93-115; Faur, 1992: 105-109; and Wachtel, 2013: 2, 245). Américo Castro made such a connection early on (see infra), and his student Stephen Gilman echoed the idea (Gilman, 1972: 57, 138).

8 In this essay, I use "modernity" in the Eurocentric sense used in the discourse of Marranism, that is, as referring to a sensibility that emerged in early modern Europe, one that was associated with a sharp rupture in the traditional patterns of European life.

9 See in particular Marks (1996).

10 Castro was preceded by Marcel Bataillon, who in his magisterial Erasme et Espagne (1937, revised Spanish translation 1950 ) established the converso background of many of the sixteenth-century authors who form part of the discussion; but Bataillon was cautious and rigorous to a fault, and avoided generalization. (Bataillon, 1937; 1995) Among later Hispanists mentioned in the Marranism literature, several of them Castro's students, are Stephen Gilman, Angel Alcalá, Albert Sicroff, Antonio Domínguez Ortíz, and Francisco Márquez Villanueva.

11 This is a revised translation of Castro (1948). On the successive stages of Castro's work, see Araya (1969).

12 For discussion of perceptions of Spain's decline and need for regeneration, see Junco (2001) and Juliá (2004).

13 See James Monroe's description of the emergence of romantic attitudes in Spain among Unamuno and others of the Genera- 
tion of '98, in reaction to Krausian liberalism; it was in keeping with this that they rejected Spain's assimilation into Europe, an attitude Monroe describes as "a difficult compromise between the progressive and traditional forces." (Monroe, 1970: 151152).

14 Putting it another way, he wrote that "[s]tatic, essentialist criteria fail to capture the fleeting reality that we pursue, the reality that can be grasped by intuition but not defined." (Castro, 1971: 35).

15 Castro insisted that he did not mean by this a stable essence. "This 'inwardness' is not a static and finished reality analogous to the classic substance; it is a dynamic reality, analogous to a function or, as I shall point out later, to an "invariant." (Castro, 1971: 98) He defined "morada vital" as "the creation by a people of a new awareness of its collective dimension, new with respect to the awareness expressed before by those who preceded it in that geographical space" (Castro, 1971: 123). See also (Szpiech, 2014: 117) and bibliography there. For a further discussion of these terms, see (Araya, 1969: 62).

16 On this circle of scholars see Rodríguez Mediano (2002); Monroe (1970).

17 While Gilman dutifully reiterated Castro's notion of caste, he insisted on the psychological and situational sources of converso subjectivism, and analyzed the converso predicament in terms that resemble those in more recent literature. A typical example: "Standardized phrases of piety, ritual gestures, calculated facial expressions, and elaborate exhibition of Christian dietary habits, all constituted a kind of non-self - dependent on unrelenting self-inspection-within which one might hope to live unnoticed. But inside this shell consciousness burned all the brighter, kindled by enforced alienation and stoked by fear, shame, pride, and, above all, resentment." (Gilman, 1972: 105106).

18 David Nirenberg has sought to make clear that Castro's use of the term "caste" includes the implication of biological reproduction, similar to that of the term "race." (Nirenberg, 2007: 77-78 and 83-84)

19 On the role of philology in the development of racial thinking, see Olender (2008). A generation ago, Edward Said provocatively excavated and brought to public attention the closely related nineteenth-century discourse of "orientalism," with its binaries of "east" and "west" that were deployed by Europeans to define themselves against the "other." Said's work, however, is highly polemical, with inevitable distortions; it is not terribly useful for disentangling the ambivalence inherent in European orientalism that will be explored here. See Said (1979).

20 "Sin el Islam i quien puede adivinir cuál hubiera sido nuestra suerte? Sin el Islam, España hubiera seguido los mismos derroteros que Francia, Alemania e Inglaterra; y a juzgar por lo que, a pesar del Islam, hemos hecho a través de los siglos, acaso hubiéramos marchado a su cabeza. " (Sánchez-Albornoz, 1943: 14-15). Cited in (Monroe, 1970: 17).

21 For a broader discussion of the complexities of nineteenth-century Spanish efforts to deal with Spain's engagement with the Muslim world, see (Martin-Márquez, 2008: 27-60).

22 “...el complicadísimo pasado medieval ibérico, con su interconexión constante de dos mundos esenciales para comprender nuestra cultura." (Marín Niño, 2009, 207. My emphasis.)

23 In his outline for a book series of that year, he maintained that "el orientalismo bajo la forma hebrea y principalmente arábiga ha penetrado en el carácter del pueblo español, dejando impreso su sello con carácter fidelísimo en su grandiosa historia, en sus costumbres, en su habla y hasta en los elementos de su sangre....El español como europeo...mirará en Grecia y Roma las civilizadores communes del Occidente; pero como habitante de la Península Ibérica recordará con placer los tiempos en que franceses é italianos acudian à beber ilustracion y ciencia en las escuelas de Andalucía." (Fernández y González, 1861: ix-x) On Fernández y González's work and thinking, see (Friedman, 2012: 137-196).

24 Castro used these inscriptions to exemplify "the root of the social system that permitted the shared common life of the three people-castes both in the Muslim south and in the Christian north." (Castro, 1971: 59-63)

25 This was not original; Menéndez Pelayo, for example, used the term "semítico-español" in reference to two Muslim figures (Avempace and Ibn Tofail) and a Jew (Ibn Gabirol). (Menéndez Pelayo, 1891: 12).

26 Nineteenth-century French authors sought to imitate an "oriental" prose that one scholar characterized as "enjoyada, aérea, ágil y rítmica, ligera y sensual, tocando casi el sutil erotismo." (Llopesa, 1996: 176)

27 "[T]he Christians did not possess enough reserves of 'Occidentalism,' or enough people to replace or transform the volume of Islamico-Judaic culture they had captured....A fortuitous accident that contributed to the weakening of Castile's not very intense Occidentalism was the death of Prince Fernando de la Cerda, heir to Alphonse X's crown." (Castro, 1954: 371)

28 On Castro's essentialism, see Castién Maestro (2006).

29 The bracketed term is in Castro's original version, Castro (1948).

30 A reference to the Berber origin of Augustine's parents.

31 For a description of the development of these themes theme in early nineteenth-century Spanish writing see (Junco, 2001: 234-236).

32 García-Arenal (2013: 7) makes the connection between Yovel and an older historiographical tradition, adding the critical remark that "to make a positive interpretation of old-fashioned negative claims does not always mean that one avoids the trap of believing in a transcendental and essentialist notion of identity."

33 In his discussion of medieval Jewish literary expression on the fourteenth-century, Castro, who did not read Hebrew, relied heavily on the Jewish poet Santob de Carrión (Shem Tov ben Isaac Ardutiel), who wrote in both Hebrew and Castilian.

34 Castro saw no reason to distinguish between the persecution suffered by medieval Jews and that suffered by conversos. The converso's particular need to dissimulate, to mask oneself, to hide a watching self behind a compliant self may have been different from the suffering of the Jew, but this difference was not relevant for his argument. In the following passage, for example, he underscored the continuity he saw between medieval Jews and early modern conversos in their responses to persecution: "[T] he Hispano-Oriental tradition has been clearly evidenced in the tendency to adopt certain spiritual modalities (illuminism, mysticism, or Erasmianism) or certain profane styles (the pastoral and picaresque narratives). It is impossible to separate the fact that Jorge de Montemayor and Mateo Alemán were descendants of converts from the meaning of [their work], for in [it] we see the intent to show human life as a dreamlike ideal or as a materialism devoid of meaning - negative idealism.... The oppressive circumstances in which New Christians found themselves revived their traditional tendency to take refuge in distant ideals." (Castro, 1954: 570. My emphasis)

35 For a discussion of similar ambivalence, albeit expressed along different lines, see Friedman (2011).

36 The locus classicus for the idea that with the coming of Christ the Jews had ceased to thrive is Romans 11. More emphatic was Augustine's declaration in his Tractatus adversus Judaeos that the Jews were "stationary in useless antiquity."

37 This has recently been noted by Anna Menny (2010: 143).

38 For a discussion of the racialization of Christian triumphalism see ibid., 68-79. See also (Boyarin, 1994: 43-56).

39 As he put it, in the course of a lengthy discussion, "We must follow the trail of the Inquisitorial ways back into the obscurity of the Castilian and Aragonese ghettos, if we wish to learn anything of their origin." (Castro, 1954: 532). "The spirit of the ghetto, new and strange, spoke through the priests of Jewish extraction who managed the Inquisition." (Castro, 1954: 535). For a rebuttal from an author on whose work Castro depended, see (Baer, 1966, vol.2: 444-456).

40 It was the Jews, according to Castro, who "instilled in the minds of the Spaniards the Semitic idea of lineage, that the body was worth more than the works accomplished by the per- 
son" (Castro, 1971: 581; see also 52, 67, 21n1). For a response, see Netanyahu (1979).

41 (Castro, 1954: 558)

42 Menéndez Pelayo wrote in a letter to Juan Valera in that year: "La Inquisición históricamente considerada, tiene un lado antipático y repugnante, y otro lado, hasta cierto punto, simpatico. El lado antipático y odioso es el fanatismo de sangre y de raza, que probablemente debimos a los judíos, y que luego se volvió contra ellos de un modo horrible." Quoted in (Millás Vallicrosa, 1956: 255-56). Benzion Netanyahu suggested that Castro may have drawn these ideas from Ernest Renan; perhaps it was Menéndez Pelayo who drew them from Renan. See (Netanyahu, 1979: 399).

43 These themes are prominent throughout Castro's discussion of medieval Jews. He maintained that "[b]efore the expulsion few Jews had reached the intellectual or literary heights" of their converso descendants; and once they left Iberian lands, most ex-conversos produced little of literary or intellectual value, because they lived "under the dogmatic censorship of the rabbis." (Castro, 1954: 575) While Alfonso X of Castile was driven to intellectual achievement by his "insatiable curiosity," "the Jew" had unpleasant ulterior motives for cultivating knowledge: namely, to "savor the delights of exercising his power and exhibiting his superiority over the caste of his lords." (Castro, 1954: 476, 472). "[The Jews'] literary, scientific, and philosophical works [in $10^{\text {th }}-12^{\text {th }} \mathrm{c}$. Muslim Spain] occupy a conspicuous place in the history of European civilization.... None of these Jews would have been what he was without Spanish Islam. When the latter declined after the twelfth century, the creative genius of the Hispano-Hebrew likewise declined." (Castro, 1954: 470)

44 Castro was not trained in Hebrew literature. But the scholarly groundwork for his inclusion of the Jews and their descendants as a vital component of Spanish history had been laid by others. Among the works that Castro cited were (Fita, 1889 and 1898; Amador de los Ríos, 1848 and 1875-1876; Millás Vallicrosa, 1942 and 1948; Baer, 1936; and Bataillon, 1937).

45 For a rather disparaging description of this relationship, as Castro saw it, see (Castro, 1954: 490-91).

46 For Révah's published address, see Révah (1967a). A summary by Francisco Cantera Burgos (1967) can be found in Sefarad, 27: 144-147. For Castro's response, see Américo Castro (1967), to which Révah responded (1967b). Cf. Carsten Wilke's remarks in (Révah, 2003: 34-36).

47 “....il n'a guère tenu compte des innombrables Judaïsants portugais qui ont vécu en Espagne en dont beaucoup ont participé à la vie culturelle et littéraire. En un mot, la dimension judaïsante du 'néo-christianisme' est délibérément sacrifiée." (Révah, 1967a: 21)

\section{REFERENCES}

Amador de los Ríos, José (1848) Estudios históricos, políticos y literarios sobre los judios de España, 2 vols. M. Díaz, Madrid.

Amador de los Ríos, José (1875-1876) Historia social, política y religiosa de los judios de España, 2 vols. Fortanet, Madrid.

Araya, Guillermo (1969) Evolución del pensamiento histórico de Américo Castro. Taurus, Madrid.

Baer, Yitzhak (1966) A History of the Jews in Christian Spain, 2 vols. Jewish Publication Society, Philadelphia.

Baer, Fritz (1936) Die Juden im christlichen Spanien, 2 vols. Akademie-Verlag, Berlin

Bataillon, Marcel (1937) Érasme et Espagne: recherches sur l'histoire spirituelle du XVI siècle. Droz, Geneva.

Bataillon, Marcel (1995) Erasmo y España: Estudios sobre la historia espiritual del siglo XVI. Fondo de Cultura Económica, Madrid.

Bodian, Miriam (2010) "Review of Yirmiyahu Yovel, The Other Within". The American Historical Review, 115: 616-617.

Boyarin, Jonathan (1994) "The Missing Keyword: Reading Olender's Renan". Qui Parle: Critical Humanities and Social Sciences, 7, 2: 43-56.
Castién Maestro, Juan Ignacio (2006) "Américo Castro ¿una visión orientalista de la realidad histórica de España?". In Actas de la jornada sobre orientalismo, ayer y hoy (Entrecruce de percepciones), edited by Morales Lezcano, Víctor. Universidad Nacional de Educación a Distancia, Madrid: 49-72.

Castro, Américo (1948) España en su historia: cristianos, moros y judios. Losada, Buenos Aires.

Castro, Américo (1949) "El enfoque histórico y la no hispanidad de los Visigodos". Nueva revista de filología hispánica, 3: 217-263.

Castro, Américo (1954) The Structure of Spanish History. Tr. Edmund L. King. Princeton University, Princeton.

Castro, Américo (1961) De la edad conflictiva. Taurus, Madrid.

Castro, Américo (1967) "Sobre el no querer entender nuestra historia". Ínsula: Revista Bibliografica de Ciencias y Letras, 22, 247: 1, 12-13.

Castro, Américo (1971) The Spaniards: An Introduction to Their History. Tr. Willard F. King and Selma Margaretten. University of California, Berkeley and Los Angeles.

Diner, Dan (2007) "Marranische Einschreibungen: Erwagungen zu verborgen Traditionen bei Hannah Arendt". In Babylon 22: Beiträge zur jüdischen Gegenwart. Neue Kritik, Frankfort am Main: 62-71.

Ehrenfreund, Jacques and Schreiber, Jean-Phillippe (editors) (2014) Les marranismes: De la religiosité cachée à la société ouverte. Demopolis, Paris.

Faur, José (1992) In the Shadow of History: Jews and Conversos at the Dawn of Modernity. SUNY, Binghamton.

Fernández y González, Francisco (1861) Plan de una biblioteca de autores árabes españoles o estudios biográficos para server a la historia de la literature arábiga en España. Manuel Galiano, Madrid.

Ferruta, Paola (2014) "In the Grip of Marranism: The Other within Europe's Multiple Modernities". In The Meanings of Europe: Changes and Exchanges of a Contested Concept, edited by Wiesner, Claudia and Schmidt-Gleim, Meike. Routledge, New York: 47-60

Fita, Fidel (1889-1898) La España hebrea, datos historicos, 2 vols. Fontenet, Madrid.

Friedman, Michal (2011) “Jewish History as 'Historia Patria': José Amador de los Ríos and the History of the Jews of Spain." Jewish Social Studies, 18: 88-126.

Friedman, Michal (2012) Recovering Jewish Spain: Politics, Historiography and Institutionalization of the Jewish Past in Spain (1845-1935). Dissertation. Columbia University.

García-Arenal, Mercedes (2013) "Creating Conversos: Genealogy and Identity as Historiographical Problems (after a recent book by Ángel Álcala)". Bulletin of Spanish and Portuguese Historical Studies, 38: 1-19.

Gilman, Stephen (1972) Spain of Fernando de Rojas: The Intellectual and Social Landscape of "La Celestina". Princeton University, Princeton.

Goode, Joshua (2009) Impurity of blood: defining race in Spain, 1870-1930. Louisiana University Press, Baton Rouge.

Gyssels, Kathleen (2012) «Le marranisme absolu dans l'œuvre d'André et de Simone Schwarz-Bart». Présence francophone, 79: 39-65

Harst, Joachim (2012) "Making Love: Celestinesque Literature, Philology and 'Marranism"'. MLN, 127: 169-189.

Jama, Sophie (2007) "L'oeuvre de Montaigne, une contribution du marranisme à l'Occident". In Identités sépharades et modernité, edited by Lasry, Jean-Claude; Lévy, Joseph and Cohen, Yolande. Presses de l'Université Laval, Québec: 157-174.

Juliá, Santos (2004) Historia de las dos Españas. Taurus, Madrid.

Junco, José Álvarez (2001) Mater Dolorosa: La idea de España en el siglo XIX. Taurus, Madrid.

Kriegel, Maurice (1998) 'Du marranisme au 'néo-judaïsme': migrations et reconfigurations identitaires dans l'Europe moderne (XV-XVIII siècles)". In Creencias y culturas, edited by Meyuhas-Ginio, Alisa and Carrete Parrondo, Carlos. Universidad Pontificia de Salamanca, Salamanca: 113-128.

Kriegel, Maurice (2002) "Le marranisme: Histoire intelligible et memoire vivante". Annales: Histoire, Sciences Sociales, 57: 323-334. 
Lindenberg, Daniel (1997) Figures d'Israël: l'identité juive entre marranisme et sionisme (1648-1998). Hachette, Paris.

Llopesa, Ricardo (1996) "Orientalismo y modernismo". Anales de Literatura Hispanoamericana, 25: 171-179.

Mansfield, Nick (2000) Subjectivity: Theories of the Self from Freud to Haraway. New York University, New York.

Marín Niño, Manuela (2009) "Arabismo e historia de España (1886-1944). Introducción a los epistolarios de Julián Ribera Tarragó y Miguel Asín Palacios". In Los epistolarios de Julián Ribera Tarragó y Miguel Asín Palacios. Introducción, catálogo $e$ indices, edited by Marín, Manuela; De La Puente, Cristina; Rodriguez Mediano, Fernando and Pérez Alcalde, Juan Ignacio. CSIC, Madrid: 11-440.

Marks, Elaine (1996) Marrano as Metaphor: The Jewish Presence in French Writing. Columbia University, New York.

Martin-Márquez, Susan (2014) Disorientations: Spanish Colonialism in Africa and the Performance of Identity. Yale University Press, New Haven.

Melamed, Yitzhak (2011) "Review of Yirmiyahu Yovel, The Other Within". The Journal of Modern History, 83: 198-200.

Menéndez Pelayo, Marcelino (1891) Discursos leídos ante la Real Academia de Ciencias. Establecimiento tipográfico de R. Fé, Madrid.

Menny, Anna (2010) "Entre reconocimiento y rechazo: los judíos en la obra de Américo Castro." Iberoamericana, 10, 38: 143150 .

Millás Vallicrosa, José M. (1942) Las traducciones orientales en los manuscritos de la Biblioteca Catedral de Toledo. Escuela de la Casa provincial caridad, Madrid.

Millás Vallicrosa, José M. (1948) La poesía sagrada hebraico-española. CSIC, Madrid.

Millás Vallicrosa, José M. (1956) “Menéndez Pelayo y la literatura hebraicoespañola". Sefarad, 16: 249-258.

Monroe, James (1970) Islam and the Arabs in Spanish Scholarship (Sixteenth Century to the Present). Brill, Leiden.

Netanyahu, Benzion (1979) "Americo Castro and His View of the Origins of the pureza de sangre". Proceedings of the American Academy for Jewish Research, 46: 397-457.

Nirenberg, David (2007) "Race and the Middle Ages" in Greer, M. R., Mignolo, W. D., and Quilligan, M., (editors), Rereading the Black Legend: the discourses of religious and racial difference in the Renaissance empires. University of Chicago Press, Chicago.

Nirenberg, David (2009) "Review of Yirmiyahu Yovel, The Other Within”. The London Review of Books, 31:14, 16-17.

Olender, Maurice (1992) The Languages of Paradise: Race, Religion, and Philology in the Ninteenth Century. Tr. Arthur Goldhammer. Harvard University, Cambridge, MA.

Pastore, Stefania (2010) Una herejía española: Conversos, alumbrados e Inquisición (1449-1559). Tr. Clara Álvarez Alonso. Marcial Pons, Madrid.

Regueiro Salgado, Begoñia (2013) "Una nueva forma de orientalismo romántico: presencia y valores de lo oriental en la obra de Gustavo Adolfo Bécquer”. Bulletin of Spanish Studies, 90: 177194.
Révah, Israel S. (1967a) Leçon inaugurale faite le jeudi 8 décembre 1966, Collège de France, Chaire de langues et littératures de la péninsule ibérique et de l'Amérique latine. Collège de France, Paris.

Révah, Israel S. (1967b) "Réplica a Don Américo Castro". Ínsula: Revista de letras y ciencias humanas, 22, 253: 5, 14-15.

Révah, Israel S. (2003) Antonio Enríquez Gómez: un écrivain marrane (v. 1600-1663), edited by Wilke, Carsten. Chandeigne, Paris.

Rodríguez Mediano, Fernando (2002) Humanismo y progreso: Pidal, Gómez-Moreno, Asín. Nívola, Madrid.

Rohr, Isabelle (2011) «'Spaniards of the Jewish Type': Philosephardism in the Service of Imperialism in Early Twentieth-Century Spanish Morocco». Journal of Spanish Cultural Studies, 12: 61-75.

Roth, Norman (1989) "Algunos de los primeros hebraístas de España y sus influencias". Miscelánea de Estudios Árabes y Hebraicos: Sección Hebreo, 37-38: 317-323.

Said, Edward W. (1979) Orientalism. Vintage, New York.

Salomon, Herman P. (1975) "The 'De Pinto' Manuscript: A Seventeenth-Century Marrano Family History". Studia Rosenthaliana, 9: 1-62.

Sánchez-Albornoz, Claudio (1943) España y el Islam. Sudamericana, Buenos Aires.

Shepard, Sanford (1971) "The Background of Uriel da Costa's Heresy - Marranism, Scepticism, Karaism”. Judaism, 20: 341-350.

Siegel, Jerrold (2005) The Idea of the Self: Thought and Experience in Western Europe since the Seventeenth Century. Cambridge University, Cambridge.

Simms, Norman (2005) Masks in the mirror: Marranism in Jewish experience. Peter Lang, New York.

Szpiech, Ryan (2014) "Américo Castro, Erich Auerbach, y la 'ciencia' historiográfica”. In Encrucijada de culturas: Alfonso X y su tiempo, Homenaje a Francisco Márquez Villanueva, edited by González Ferrín, Emilio. Fundación Tres Culturas, Seville:101-124.

Trigano, Shmuel (2000) "Le marranisme, un modèle multidimensionnel". Pardès, 29: 261-269.

Trigano, Shmuel (2012) «'Etrangers et résidents': Ce qui, dans le judaïsme, rend possible le marranisme». In La Civilisation du judaïsme: De l'exil a la diaspora, edited by Trigano, Shmuel. Eclat, Paris: 295-303.

Yovel, Yirmiyahu (2009) The Other Within: The Marranos: Split Identity and Emerging Modernity. Princeton University, Princeton.

Wachtel, Nathan (2007) "Théologies marranes: Une configuration millénariste". Annales. Histoire, Sciences Sociales, 62: 69-100.

Wachtel, Nathan (2013) The Faith of Remembrance: Marrano Labyrinths. Tr. Nikki Halpern. University of Pennsylvania, Philadelphia.

Zahavi, Dan (2008) Subjectivity and Selfhood: Investigating the First Person Perspective. MIT, Cambridge, MA.

Zepp, Suzanne (2014) An Early Self: Jewish Belonging in Romance Literature, 1499-1627. Tr. Insa Kummer. Stanford University, Stanford. 